\title{
ANALISIS IMPLEMENTASI KEBIJAKAN PENDIDIKAN UU NO. 20 TAHUN 2003 TERHADAP PENDIDIKAN NASIONAL DI INDONESIA
}

\author{
Indah Mayangsari ${ }^{1}$, Fisca Aprita Dewi ${ }^{2}$, Nurfadila ${ }^{3}$, Migfar Rivadah ${ }^{4}$ \\ Universitas Ahmad Dahlan Yogyakarta \\ 1indah1800031214@webmail.uad.ac.id \\ 2fisca1800031214@webmail.uad.ac.id \\ ${ }^{3}$ nurfadila1800031232@webmail.uad.ac.id \\ ${ }^{4}$ migfar1800031252@webmail.uad.ac.id
}

\begin{abstract}
The implementation of education policy can be interpreted as an action or carrying out a policy which leads to the education sector in order to achieve the desired goals. To achieve the desired educational policy objectives have a process in implementing education policies including 1) preparing for the implementation of education policies, 2) implementing education policies with a trial period, 3) implementing real education policies accompanied by supervision and control, 4) conducting an evaluation of education policies. education policy has characteristics to improve education by having educational goals, fulfilling legal-formal aspects, has an operational concept, is made by the authorities, can be evaluated, and has a systematic, later in implementing education policy itself it is necessary to know continuously or be concerned with various factors outside of education. namely political factors, legal factors, social factors, economic factors that directly or indirectly affect the educational policy program made, to achieve the desired implementation of educational policies and achieve defining objectives have strategies that must be mastered, namely communication, resources, disposition., and bureaucratic structures. This is aimed at realizing the desired implementation of educational policie.
\end{abstract}

Keywords : education, politic, rules

\begin{abstract}
Abstrak - implementasi kebijakan pendidikan dapat diartikan sebagai suatu tindakan atau pelasanaan suatu kebijakan yang mengarah pada bidang pendidikan guna mencapai tujuan yang diinginkan. Untuk mencapai tujuan pendidikan yang diinginkan memiliki proses dalam melaksanakan kebijakan pendidikan meliputi 1) mempersiapkan pelaksanaan kebijakan pendidikan, 2) melaksanakan kebijakan pendidikan dengan masa percobaan, 3) melaksanakan kebijakan pendidikan yang nyata disertai dengan pengawasan dan pengendalian. 4) melakukan evaluasi kebijakan pendidikan. Kebijakan pendidikan memiliki cirri-ciri untuk meningkatkan pendidikan dengan memiliki tujuan pendidikan, memenugi aspek legal-formal, memiliki konsep operasional, dibuat oleh penguasa, dapat dievaluasi, dan memiliki sistematis, kemudian dalam melaksanakan kebijakan pendidikan itu sendiri perlu diketahui secara terus menerus atau peduli dengan berbagai factor di luar pendidikan yaitu factor politik, factor hokum, factor social, factor ekonomi yang secara langsung mempenfaruhi program kebijakan pendidikan yang dibuat, untuk mencapai pelaksanaan yang diinginkan kebijakan pendidikan dan mencapai tujuan yang telah ditetapkan mempunyai strategi yang harus dikuasai yaitu, komunikasi. Sumber daya, disposisi, dan struktur birokasi. Hal ini bertujuan untuk mewujudkan implementasi kebijakan pendidikan yang diingikan.
\end{abstract}

Kata kunci : Pendidikan, Politik, Kebijakan

\section{PENDAHULUAN}

Kebijakan berasal dari kata "Policy" berasal dari bahas inggris yang berarti sebuah rencana yang terdapat tujuan dan sebuah keputusan dari pemerintah, partai politik, dan lain-lain. Secara bahasa kebijakan berasal dari yunani yang berarti kota. Latar belakang adanya kebijakan pendidikan merupakan adanya sebuah masalah dari pendidikan itu sendiri. Masalah yang terjadi dalam kebijakan pendidikan muncul ketika adanya kesenjangan antar tujuan pendidikan yang sudah di tetapkan penyelenggara pendidikan. Proses implementasi pendidikan merupakan ketentuan akhir yang paling penting dalam pembuatan sebuah 
kebijakan. Implementasi kebijakan adalah proses dalam pembuatan kebijakan. Implementasi kebijakan pendidikan merupakan proses yang dinamis dimana dalam pelaksanaan kebijakan melakukan sebuah aktivitas yang pada akhirnya akan menghasilkan suatu hasil yang sesuai dengan sasaran atau tujuan dari kebijakan tersebut. Tujuan dari implementasi kebijakan adalah agar tujuan dari kebijakan dapat tercapai dan ter implikasikan. Dalam proses implementasi kebijakan pendidikan ada beberapa tahap yang perlu di lalui, pendekatan dan langkahlangkah yang ditempuh. Hal ini demi untuk mewujudkan keberhasilan dari implementasi kebijakan, dan juga kebijakan dalam bidang pendidikan.

Konsep pendidikan di Indonesia telah dirumuskan dalam pembukaan UUD 1945 dengan pokok kalimat "mencerdaskan kehidupan bangsa". Kalimat tersebut memiliki makna bahwa pendidikan merupakan salah jalan untuk mencerdaskan generasi muda bangsa Indonesia. Undang0undang No.20 Tahun 2003 menyatakan bahwa "Pendidikan Nasional bertujuan untuk mengembangkan kemampuan dan membentuk watak serta peradaban bangsa guna mencerdaskan bangsa dan mengembangkan potensi peserta didik agar menjadi manusia yang beriman dan bertakwa kepada Tuhan Yang Maha Esa, sehat berakhlak mulia, cakap, berilmu, kreatif, mandiri dan menjadi warga negara yang bertanggung jawab dan demokratis."

UU No. 20 Tahun 2003 di buat untuk menjawab segala tantangan yang terjadi di kehidupan masa yang datang atau mungkin masa setelahnya, sebuah kebijakan yang telah di implementasikan akan mengalami berbagai persoalan yang di hadapi. Seiring berjalan nya waktu penetapan
UU No 23 tahun 2003 mengenai sistem pendidikan Nasional sudah seharusnya di evaluasi dan di revisi untuk menyesuaikan dengan kebutuhan di zaman yang semakin maju, terutama pada pasal-pasal yang masih krusial. (Abdul, Wahyu, Adiyatna, \& Fazlur , 2021)

Pendidikan merupakan salah satu hal yang terpenting di setiap negara yang menjadi perhatian yang cukup serius. Semakin berkembangnya zaman pendidikan di Indonesia mengalami perubahan yang sangat signifikan. Setiap kebijakan pendidikan yang di bentuk akan tertuang pada sistem pendidikan nasional, kebijakan pendidikan tersebut hasil pemikiran para tokoh pendidikan dengan tujuan agar sistem pendidikan dapat menyatukan konsep dengan kebutuhan dari masyarakat, oleh karena itu pendidikan harus bisa membawa perubahan untuk memuat bangsa Indonesia yang cerdas dan memiliki kemampuan yang luas serta bermartabat dan memiliki akhlak yang mulia. (Matlani \& Khunafi, 2019)

Pada kenyataannya System pendidikan tersebut belum bisa dilaksanakan sesuai harapan yang diinginkan. Salah satu contoh yang dihadapi masyarakat sampai sekarang ini adalah pelayanan pendidikan yang belum merata untuk seluruh lapisan masyarakat. Sudah seharusnya dalam pelayanan pendidikan untuk seluruh masyarakat harusnya di implementasikan sesuai dengan konstitusi yang di berlakukan. Hakikatnya pelayanan pendidikan tidak hanya diberikan kepada orang yang berkuasa, melainkan wajib diberikan kepada seluruh secara adil dan merata. Tentunya ini berkaitan dengan kebijakan-kebijakan pemerintah yang harus direalisasikan secara adil dan merata. . Dalam pasal 31 ayat 4 UUD 1945 menyatakan bahwa pemerintah 
memiliki sebuah kewajiban konstitusi untuk memfokuskan anggaran untuk pendidikan kurang lebih 20\% dari dana APBN dan APBD hal ini berguna untuk mewujudkan penyelenggaraan pendidikan nasional. (Rahmawati, 2016).

Dalam proses implementasi kebijakan pendidikan merupakan penentuan terakhir yang sangat penting dari keseluruhan dalam membuat kebijakan termasuk kebijakan di bidang pendidikan. Artinya, sebaik apa pun atau sebagus apa pun formulasi dan rumusan kebijakan yang dihasilkan tidak akan berarti jika rumusan tersebut tidak dilanjutkan proses implementasi. Maka dari itu, sesederhana apa pun sebuah kebijakan tetap tidak untuk mengatakan buruk terhadap rumusan dan formulasi dari kebijakan, jika telah dilaksanakan maka nilai manfaat dapat dirasakan.

Pelaksanaan suatu kebijakan pendidikan sebagai penentu berhasilnya atau tidak dari kebijakan pendidikan dimana harus sesuai dengan prinsip Good Governance, yaitu akuntabilitas, transparansi, fairness dan responsivitasi hal ini diharapkan agar kebijakan pendidikan dapat membuat mutu pendidikan menjadi lebih baik. Dalam proses pelaksanaan implementasi kebijakan pendidikan merupakan hal yang sangat penting bahkan bisa lebih penting dari proses pembuatan kebijakan pendidikan itu sendiri, karena dalam proses implementasi kebijakan menjadi jalan penentu atau penghubung dari perumusan kebijakan dengan hasil yang telah di tentukan.

Melihat dan meninjau landasan hukum yang ada, secara langsung UUD 1945 sebagai normative problem memberikan amanat kepada pemerintah agar pelayanan pendidikan diberikan tanpa memilahnya, ataupun mengakui adanya jalur pendidikan dalam UU Sisdiknas maka, permasalahan masih ditimbulkan terkait implementasi kebijakan pendidikan menengah dalam kebijakan pendidikan di Kabupaten dan Kota. Problematika di atas dapat kita ketahui di lapangan yakni kurangnya konsisten pada keputusan teknis dan memberikan kesan yang masih memihak kepada elite politik dan birokrasi lokal dalam level pembuatan kebijakan mikro baik dalam bentuk perda (peraturan daerah), dan diikuti oleh Keputusan Bupati atau Walikota. Dalam fungsi legitimasi, peran DPRD Kabupaten dan Kota belum begitu optimal. Begitu juga dalam fungsi pengawasan dewan dalam pelaksanaan perda dinilai masih lemah Dalam implementasi kebijakan pendidikan memerlukan sebuah peraturan yang jelas, dengan adanya tata kelola yang baik di antara pemerintah dan masyarakat. Selain diperlukan peraturan yang jelas, dibutuhkan juga kejelasan pada komunikasi antar organisasi, agar tujuan yang ingin di capai dapat terwujud.

\section{METODE PENELITIAN}

Penelitian ini menggunakan studi literatur atau literature research. Penelitian ini menggunakan artikel jurnal dan buku untuk mengumpulkan data penelitian. Pengumpulan data ini berupa data-data literatur artikel jurnal yang berkaitan dengan "implementasi kebijakan pendidikan". Selanjutnya data yang telah terpilih dikumpulkan kemudian dipilih, disajikan, dan dianalisis serta diolah agar data menjadi ringkas dan sistematis (Elih, 2020: 19-20).

\section{HASIL DAN PEMBAHASAN}

Semakin perkembangan zaman maka hal itu membuat pola kehidupan masyarakat menjadi lebih maju dan lebih modern. Seiring dengan berkembangnya globalisasi yang semakin maju maka setiap lembaga pendidikan dituntut untuk terus 
berkembang menyesuaikan kebutuhan masyarakat. Adanya sebuah kebijakan pendidikan merupakan salah satu jalan untuk setiap lembaga pendidikan untuk dapat mengembangkan semangat untuk lebih maju lagi dari lembaga pendidikan lainnya. Lembaga pendidikan dapat memberikan kebebasan berkreasi dan kebebasan dalam mengembangkan potensi sesuai dengan minat dan bakat setiap peserta didik

Implementasi kebijakan pendidikan sebagai tindakan yang dilakukan baik itu individu maupun kelompok pemerintah dan swasta yang di tunjuk untuk mencapai tujuan kebijakan yang telah di tentukan sebelumnya. Tindakan yang dimaksud disini adalah sebuah tindakan dari sebuah usaha untuk mentransformasikan sebuah keputusan dalam istilah

Kebijakan pendidikan merupakan sebuah rumusan yang bertujuan untuk mewujudkan sebuah pendidikan nasional melalui lembaga sosial baik itu lembaga pendidikan formal, informal dan non formal. Maka dari itu, kebijakan pendidikan jika tidak segera di aplikasikan maka hal itu tidak diketahui tingkat keberhasilannya.

Mengimplementasikan berarti menyediakan sebuah sarana untuk melaksanakan sesuatu. Dapat di tarik kesimpulan bahwa implementasi kebijakan pendidikan itu merupakan cara untuk menerapkan atau melaksanakan sebuah kebijakan untuk mencapai sebuah tujuan agar dapat terwujud. Kebijakan dalam bidang pendidikan dilaksanakan agar dapat memahami kebijakan itu sendiri dimana kebijakan tersebut merupakan bagian dari kebijakan publik.

Implementasi pendidikan merupakan sebuah proses yang sangat penting dan juga begitu menentukan. Berhasilnya sebuah kebijakan pendidikan dapat dilihat dari langkah-langkah implementasi. Sebaik apapun dari kebijakan pendidikan tetapi jika tidak di implementasikan hal itu tidak bermanfaat untuk semua orang. Dalam proses penyusunan implementasi kebijakan pendidikan melibatkan beberapa perangkat publik seperti hukum, politik, administrasi dan organisasi hal ini untuk tercapainya dari kebijakan pendidikan itu sendiri.

Proses langkah atau tahapan dalam implementasi kebijakan pendidikan sebagai berikut:

1. Persiapan dalam implementasi kebijakan kurang lebih 6 bulan, hal ini termasuk sebuah sosialisasi dan juga pemberdayaan dari para pihak yang melaksanakan kebijakan pendidikan baik itu pemerintah maupun birokrasi masyarakat. Proses sosialisasi dan pemberdayaan dilaksanakan dengan cara seperti menyebarluaskan informasi kepada masyarakat.

2. Tahapan yang kedua dalam mengimplementasikan kebijakan pendidikan dilakukan dengan tanpa saksi atau dengan masa uji coba yang memakan waktu kurang lebih 6-12 bulan serta di perbaiki jika diperlukan.

3. Tahapan yang ketiga dilaksanakan dengan saksi dalam melaksanakan kebijakan pendidikan setelah sebelumnya dilakukan masa uji coba selesai, tahapan ini dilaksanakan dengan pengawasan dan pengendalian.

4. Tahapan yang terakhir yaitu implementasikan kebijakan pendidikan dilaksanakan selama tiga tahun, disertai dengan evaluasi kebijakan pendidikan. 
Karakteristik Kebijakan Pendidikan

Menurut Gunawan dalam Arwildayanto, Arifin S \& Warni T,S (2018) ada enam karakteristik khusus untuk meningkatkan kebijakan pendidikan, yaitu:

1. Memiliki tujuan pendidikan.: Kebijakan pendidikan tentunya harus memiliki tujuan pendidikan, namun tujuan tersebut bersifat lebih khusus. Yang dimana tujuan pendidikan tersebut harus jelas dan terarah untuk berkontribusi dalam penyelesaian masalah pendidikan.

2. Memenuhi legal-formal: Untuk memberlakukan kebijakan pendidikan, tentunya terdapat syarat yang harus terpenuhi agar kebijakan yang dibuat dapat diakui secara sah, serta syarat konstitusional sesuai dengan yang berlaku pada sebuah wilayah

3. Memiliki konsep operasional: kebijakan pendidikan merupakan panduan yang bersifat universal, untuk itu sebuah kebijakan harus mempunyai manfaat yang operasional agar dapat diimplementasikan untuk mencapai sebuah tujuan dalam pendidikan. Kebijakan pendidikan disini adalah fungsi pendukung untuk mengambil sebuah keputusan.

4. Kebijakan pendidikan di buat oleh orang yang ahli di bidang nya, hal ini agar tidak sampai terjadi kesalahan atau menyimpang pada pendidikan dan di luar pendidikan.

5. Dapat dievaluasi: Sebuah kebijakan tentunya masih harus untuk dievaluasi. Jika suatu kebijakan yang dibuat itu baik dan layak untuk diberlakukan, maka akan tetap dipertahankan dan dikembangkan, sebaliknya jika dalam suatu kebijakan terdapat kesalahan maupun kekurangan, maka diharuskan untuk
6. Diperbaiki secara sistematis: kebijakan merupakan sistem. Oleh karena itu, kebijakan harus memiliki sistematika yang jelas dari segala aspek. Selain itu, sistematika tersebut juga dituntut untuk memiliki efektivitas, efisien dan subtanabilitas yang tinggi agar kebijakan yang berlaku tidak bersifat diskriminatif. Hal itu perlu diperhatikan agar kebijakan yang akan diberlakukan tidak menimbulkan kecatatan hukum.

\section{Faktor pendukung serta faktor keberhasilan implementasi kebijakan pendidikan}

Dalam bidang pendidikan, kebijakan pendidikan memiliki faktor yang menentukan kebijakan diantara-Nya ialah : 1. Komunikasi, 2. Sumber daya, 3. Disposisi, dan 4. Struktur birokasi. Faktor-faktor di atas saling berkaitan satu sama lain. Dengan adanya komunikasi antara pelaksanaan program kebijakan secara efektif maka kebijakan pendidikan akan terlaksana dengan baik. Begitupun kebijakan pendidikan harus memiliki dukungan dari sumber daya manusia yang memadai, yang memiliki kecukupan dalam kualitas pengetahuan, karakter, serta memiliki kecakapan atau keterampilan kualitas implementor yang bisa melingkupi terhadap seluruh kelompok yang menjadi sasarannya.

Faktor yang turut andil dalam mendukung keberhasilan implementasi kebijakan pendidikan ialah:

1. Tidak adanya hambatan implementasi;

2. Sumber daya (resources) tersedia secara memadai;

3. Kebijakan pendidikan yang baik dan bagus;

4. Adanya kesepahaman;

5. Kesepakan dengan tujuan pendidikan; 
6. Urutan ditetapkan terhadap tugas dengan tepat;

7. Komunikasi juga koordinasi yang lancar;

Adapun faktor yang menghambat keberhasilan implementasi kebijakan pendidikan diantara-Nya:

1) Tak bisa diimplementasikan: Implementasi yang tidak berhasil (Unsucsessful implementation) menyebabkan kegagalan kebijakan.

2) Kebijakan buruk (Bad policy): perumusan secara asal-asalan, kondisi internal belum memiliki kesiapan dan kondisi eksternal yang kurang memungkinkan.

3) Implementasi buruk (Bad Implementation): pelaksanaan belum bahkan tidak memahami petunjuk pelaksanaan, terjadinya kesenjangan implementasi (Implementation gap), dll

4) bernasib buruk (badluck).

Pada kenyataannya, implementasi kebijakan tidak selalu berjalan dengan baik. Adapun faktor diantara-Nya : 1) Faktor dari organisasi, dalam implementasi kebijakan pendidikan melibatkan dan juga perlu dukungan banyak dari organisasi. 2) Faktor Politik, berupa faktor non-teknis: a) legislasi mengenai isu-isu yang masih abstrak atau belum jelas. b) log-rolling, gagalnya dalam implementasi kebijakan yang di akibatkan kesalahan saat proses legitimasi.

\section{KESIMPULAN DAN SARAN}

Kebijakan merupakan cara dalam melaksanakan atau menerapkan suatu kebijakan untuk mencapai suatu tujuan yang telah di tentukan. Tujuan dari implementasi kebijakan adalah agar tujuan dari kebijakan dapat tercapai dan ter implikasikan. Proses langkahlangkah dalam mengimplementasikan kebijakan pendidikan sebagai berikut: 1) Persiapan. 2) Implementasi kebijakan pendidikan dilaksanakan tanpa saksi (masa uji coba) 3) Implementasi kebijakan pendidikan dengan sanksi. 4) Evaluasi. Sebaik apapun sebuah kebijakan jika tidak di implementasikan maka tidak akan ada manfaatnya.

\section{DAFTAR PUSTAKA}

Abdul, R., Wahyu, N., Adiyatna, A., \& Fazlur , M. R. (2021). Analisis UU Sistem Pendidikan Nasional Nomor 20 Tahun 2003 dan Implikasinya Terhadap Pendidikan di Indonesia. JOEAI (Journal of Education and Instruction), 100.

Arwildayanto, Arifin S, Warni $\mathrm{T}$ S . (2018), Analisis Kebijakan Pendidikan Kajian Teoretis, Eksploratif, dan Aplikatif", Jakarta; CENDIKIA PRESS.

Matlani, \& Khunafi, A. Y. (2019). Analisis Kritis UndangUndang Sisdiknas Nomor 20 Tahun 2003. Jurnal llmiah Iqra', 82-83.

Rahmawati, S. (2016). Analisis Kebijakan Pendanaan Pendidikan. Repository Universitas PGRI Yogyakarta, 16.

Tilar, H.A.R dan Riant Nugroho. (2008). Kebijakan Pendidikan. Jakarta: Pustaka Belajar.

Yuliah, E. (2020). Implementasi Kebijakan Pendidikan (The Implementation Of Educational Policies). Jurnal at-Tadbir: Media Hukum dan Pendidikan, 30 (2), 17-20 